ERRATUM

Aram Hur

\title{
ADAPTING TO DEMOCRACY: IDENTITY AND THE POLITICAL DEVELOPMENT OF NORTH KOREAN DEFECTORS-ERRATUM
}

doi: https://doi.org/10.1017/jea.2017.30, Published by Cambridge University Press, 24 January 2018.

The original publication of this article had "Research Note" as part of the article title. "Research Note" is the article type and should not have been included in the title.

The editor and publisher regret this error, and the original has since been amended.

\section{REFERENCE}

Hur, Aram. 2018. The Journal of East Asian Studies 18(1): 97-115. doi: 10.1017/jea.2017.30. 